\title{
Closing the gap? \\ Overcoming limitations in sociomaterial accounts of early literacy
}

\author{
Cathy Burnett, Guy Merchant, Sheffield Hallam University, UK \\ Michelle Neumann, Griffith University, Australia
}

\begin{abstract}
This article uses a sociomaterial perspective to explore how deficit views of young children's language and literacy are sustained and can be challenged. Foregrounding the notion of multiplicity, it considers how diverse sociomaterial relations work to uphold particular kinds of practice and particular arrangements of bodies and things over others. These relations may interfere with and interface with each other in different ways, sometimes sustaining but also potentially disrupting deficit discourses and practices. Our sociomaterial perspective is illustrated with a short vignette from a study of children and touchscreen tablets in an early years setting. An initial analysis is followed by a series of alternate and tentative tracings of other kinds of relations that play through those moments. The article contributes to debates about social inequality by troubling the certainties generated though deficit models of children's literacy, whilst working proactively to envision and produce alternate possibilities that foreground the potentialities generated as people and other materials assemble together.
\end{abstract}

Keywords: sociomaterial, early childhood, literacy, multiplicities, deficit, bodies

\section{Introduction}

Deficit perspectives on the language of children from working class and minority ethnic backgrounds have surfaced and re-surfaced over many years, amplified by rhetoric about the demise of standard English and the paucity of spoken language within the home. These beliefs are often set against a background narrative of persistent economic and social disadvantage. More recently concerns have been expressed that too much screen time leaves too little time for talk, playing into moral panic about the corrosive effect of new technologies and re-assembling with a deficit view of language. At the same time there has been a worrying interest in the idea of a 'word gap' between children from the wealthiest and poorest families (Fernald, Marchman, Weisleder, 2013; Hart and Risley, 1995), leading to a plethora of interventions designed to support vocabulary development amongst children in areas of socio-economic disadvantage (e.g. Quigley, 2018). Sociocultural research has done much to challenge such perspectives (Heath, 1983; Wells, 1999) and to question the premise and reliability of the underpinning research (Adair, Colegrove and McManus, 2017; Baugh, 2017). Nevertheless, these ways of thinking are pervasive and continue to influence educational practice in multiple ways, bolstered by reductivist educational policies. A recent survey, for example, suggested that many UK teachers believe the 'word gap' is increasing, and this has significant implications for children's educational attainment (Harley, 2018). In many ways, then, the challenges we face, as educators committed to social equity, remain much as they were fifty years ago (for example, see Creber,1972).

Whilst teachers and researchers continue to grapple with diversity, difference and disadvantage, the sociomaterial relations of professional communities have been reconfigured as they adapt to changes in school governance, administration and communication. New shifts in policy, practice and professional learning have reworked ideas about deficit and these are now recycled through neoliberal networks. In England, for example, we see how schools work to manage their public profiles in a highly-marketised system in which improvement, levels of attainment and inspection ratings perform various forms of 
competitive advantage. Easily accessed databases of 'what works' in education have gained in influence (Hattie, 2008; EEF, 2018; Institution of Education Sciences, 2018), teachers turn to Twitter, Facebook and 'rockstar teachers' for inspiration (Kelly and Antonio, 2016; Guest, 2018), and certain kinds of orthodoxies gain traction and credibility as they do so, often propping up the pedagogies of poverty that continue to sustain social inequalities (Comber, 2014; Cummins, 2009).

Importantly, deficit perspectives do not provide the only ways in which educators understand what children do. Teachers' perspectives are often framed by multiple and seemingly conflicting discourses of childhood, literacy and education and these intersect in complex ways (Burnett et al., 2015; Alsup, 2006). For instance, teachers may be just as likely to celebrate children's creativity and wellbeing as they are to foreground specific skills (or the lack of them), and certainly focusing on what children can do (rather than what they cannot) has led to empowering approaches to literacy provision (e.g. Comber and Kamler, 2005; Souto-Manning and Yoon, 2018). However, the irony is that overly simplistic analyses of children's perceived underachievement can lead to narrow, prescriptive approaches in language and literacy teaching that fail to provide the rich, meaningful experiences that could do much to foster children's linguistic and literacy repertoires. As McCarty (2015: 70) argues, 'Policy discourses have material consequences for their subjects.'

In recent years, as the articles in this special issue illustrate, research from new materialist and posthuman perspectives has begun to unsettle the ways of knowing that are sustained through such policy discourses. Constellating around a relational ontology, such work challenges the individualist view of literacy development upheld by cognitive-psychological research, but also complements sociocultural accounts to foreground the material, embodied and affective dimensions of young children's meaning making (e.g. see Kuby, Spector and Thiel, 2019). Our own contribution to this body of work is a sociomaterial orientation to early literacy which is inflected both by theories of affect (Massumi, 2002) and by the work of scholars associated with post Actor Network Theory (including Law and Hassard, 1999; Mol, 2002; Law and Mol, 2002). The approach builds on a conceptualisation of people and things as 'relational effects' (Law, 2008: 632), holding these to be produced in relation rather than as separate entities. As such it aims to contribute to debates about social inequality by troubling the certainties generated though deficit models of children's literacy and the ways of knowing they depend upon, whilst working proactively to envision and produce alternate possibilities that foreground the potentialities generated as people and other materials assemble together (see Authors, 2018; 2019).

In developing this sociomaterial perspective, we have adopted a variety of ways of tracing how relational effects articulate with different kinds of literacy in early years and primary school settings. However, to date - in line with much other literacy research that might be variously described as posthuman - our focus has been limited to what happens in specific locations, whether these are schools, early years classrooms, virtual worlds, or combinations of these. Our primary orientation has been to look down (Kwa, 2002) into the details of what goes on in the moment in order to examine the varied sets of relations that swirl through educational practice. In this article, we explore what this approach offers but also consider its limitations, suggesting that, while it may enliven our sensitivity to what children $d o$, further disrupting the deficit models of literacy that sociocultural accounts have done so much to challenge, a focus on what we think matters in the moment is only part of the story and can easily divert attention from the ways in which inequality shapes children's lives and educational experiences. Specifically, we argue that a focus on the relational effects that 
produce educational encounters should acknowledge those relations that stretch beyond classrooms as well as those that operate within them, and consider the multiple and interimbricated material effects that inflect young children's literacies in educational settings.

In what follows, we begin by outlining and exemplifying our sociomaterial approach with reference to a short vignette of children and touchscreen tablets in an early years setting. Next, we introduce a series of alternate and tentative tracings of other kinds of relations that play through those moments. We consider how such relations work to uphold particular kinds of practice and particular arrangements of bodies and things over others, thereby favouring groups of children who perform and reproduce accepted and acceptable ways of being and doing. Finally we sketch a possible agenda for research that works with a focus on materiality, embodiment and affect to better account for relationships between social inequality and materiality in educational settings, but that also includes an activist dimension, through which researchers work disruptively to challenge and unsettle the kinds of practices that sustain inequality.

\section{Making meanings in the classroom}

Our vignette is crafted from observations conducted during a week-long small scale study, investigating how touchscreen tablets were taken up by young children in the context of ongoing early years activity. In doing this our interest often narrowed to what touchscreen tablets became as they came into relation with children and other things in this early years setting. We generated accounts of what happened using fieldnotes, reflective writing and video data from different points of view. This opening vignette follows a single child (J) moving across the classroom space as he encounters different atmospheres, materials (including iPads), adults and children. While we cannot know how $\mathrm{J}$ felt or what impelled him to act as he did, the story purposefully includes our own actions as embodied and embedded adults who are negotiating researcher roles for ourselves, and as such provides some insight into how felt experience plays in to what happens in the moment, as well as how adults' actions help produce what children do, and indeed the sense that is subsequently made of it. It is worth noting here that this event took place on $31^{\text {st }}$ October, Halloween, and some children were wearing fancy dress costumes.

$J$ - in a skeleton $t$-shirt- is circulating the classroom as Spider-Man, reaching up into the sky to shoot webs from his hands and using them to propel himself across the space. He ends up by the sandtray where he starts taking handfuls of sand and sifting it onto the floor. Ifeel slightly worried-should I intervene? I'm sure this can't be very good for the carpet. He looks at me so I ask if there is anything he can take into the tray. He gets a digger and starts moving it round, heaping up the sand as he goes. He tells me he's building a mountain (or maybe that's what I say to him, I can't remember). And he keeps on shifting the sand about, making the mountain higher and wider. I ask him what's inside the mountain and he reaches in as if to pull something out. As he does so, his clenched hand splays out - a spider. The spider comes at me, then back into the mountain, then at me again and back again. Guy appears on my left and places an iPad into the sandtray in front of the mountain. J sets it up so it can film the things in the sandtray. He leans down and looks at it, blows at it, flicks sand at it for a bit. Then the music from the Lion King app blares out from another iPad across the room and he drifts off towards it, to the table where $K$ and L are exploring apps. He stays there for a while, before drifting off again, and eventually picking up his Spider-Man routine again, alone in the middle of the room, spanning the space with large stretching movements and quick jabs into the air. 
In considering this brief episode from a sociomaterial perspective, we might be interested in the ways in which activity builds and dissipates, and in the continuities (spider web travel) and shifts in activity (from spider play to sand flicking). We might also notice how spiders dance like a leitmotif across J's play- first Spider-Man, then spiders in a mountain, then back to Spider-Man, as different embodied encounters with space, with sand, with diggers, open out new possibilities. As Daniels (2018) has explored, such embodied movement and sensory engagement seem to play an important role in keeping such activity going, and this seems to be the case, although it is hard to tease out relations between movement, sensation and meaning. Does bodily movement across the classroom stimulate the web swinging, or does web swinging necessitate movement, for example? And is it the feel of sand running through fingers that leads to piling it into a mountain, or does the idea of the mountain prompt the sand-play, with its shape and size forming in ways that feel 'right' or possible, when sifted and moulded by small hands? It feels likely that these things are deeply intertwined, and complicated further by habitual ways of being in this setting.

In our telling of these events, imagined worlds entangle with bodily relations and with the stuff in the classroom. Our sociomaterial perspective helps us articulate these complex, interweaving relations. And yet in this educational setting, certain kinds of relations with stuff gain more credibility than others. In Cathy's uncertain attempt to join J's play and Guy's placing of an iPad in the tray to encourage filming, we see how adults work to shape and legitimise what children do, inviting them into the kinds of material-social-textual engagements that align with accepted ideas about the pertinent genres of childhood. Cathy encourages $\mathbf{J}$ to name the world he is creating: and so the pile of sand must be a mountain and the hand sinking into the pile must also fit the narrative. J quickly catches on and readily obliges - his hand is a spider. Playing with sand - for Cathy, it seems - is somehow better if it is being used to create a mountain, particularly if the sand is kept in the tray where it belongs. Enjoying the sensual quality of the sand - if that is what $J$ is doing - might be seen to fit an earlier stage on an imagined developmental pathway; now there 'should be' an element of representation. And of course, with regulation (sand in the tray and not on the carpet) comes socialisation in the form of acceptable behaviour.

Guy's intervention was perhaps more open, offering the materialisation of sand and trucks as image, images that might invite different kinds of engagement (imaginative or exploratory perhaps). But Guy's introduction of the iPad to the sandtray - and the invitation to mediatise the activity through photography or video - disrupts the spider-mountain storying just as much as it introduces new possibilities, and the quality of the play shifts as this happens. Indeed Guy's fieldnotes of the same episode evoke a sense of disappointment:

\section{$J$ 's playing in the sandtray with diggers now. Solitary. I wonder what would happen if I put} the iPad on video. I stick it in the sand filming. It doesn't seem to work at all. In fact it spoils his game and off he goes. He hears the Lion King app start up, and he's back for a few minutes, but it doesn't hold his attention. Off he goes again.

We might see these adult moves as interruptions, interventions or as different kinds of invitations: an invitation to storying (from Cathy) and an invitation to filming (by Guy) invitations that seem predicated on notions of human development and mastery and on what adults $d o$ when they are with children. And in each case, the invitation appears to be taken up, even if it is hard to judge whether this is in delight or compliance. This allows for the coherent narratives that suit our researcher-educators' interest in making sense of children's activity, narratives that in turn seemed to shape children's ongoing embodied activity. Our 
own performances, it seems, played into these children's performances, or at least they appeared to do so, and our attempts to read a coherent narrative into events perhaps themselves helped to shape what happened. Running through both accounts is an enthusiasm (implicit perhaps) for ensuring that what children do with iPads 'fits in', that it can be made sense of (whether as a recognisable form of narrative play, or as a legitimate use of iPads). Yet at the same time there is an acknowledgement that the embodied Spider-Man play may have some significance, too - as in the following:

I move back down to the book corner. J is Spider-man. Definitely. He moves like a dancer. Perfect balance, landing in that characteristic running squat position. He fires out imaginary webs at Cathy, at the other children. He uses a claw like grip as he jumps between the buildings, from rooftop to rooftop. I'm going to film Spider-man. J knows it. He plays to the camera. I show him a bit of the playback. He grins and then he's off again doing more Spider-man moves.

Here it seems as if what counts is the body in motion. Sandtrays, adults, and skeleton t-shirts appear to take a back seat in this becoming. $\mathrm{J}$ is engaged in an act of bodying in which interest and desire seem present and perhaps the filmmaking legitimises this - at least for an instant. We are reminded of the way in which Manning writes about the bodying dynamic:

'The body' is paradoxical precisely because it has never existed as such. It comes to form, it breeds figures, but it never 'is'. Body is always a verb, an activity of bodying, a becoming-active of the paradoxical tendings - the disequilibriums, the multiple balances - that incite it to co-compose, dynamically, relationally, with the world. What we have come to know as 'body' is felt, as wonder-ful paradox, but only in the moving, and what is felt is not its exteriority or its external image but the withness, the in-actness of the event coursing through it. Body is event. Dancing event. (Manning, 2014: 184)

But yet in spite of a heightened sensitivity to the way that J-as-Spider-man moves, it could still be said that these episodes are very ordinary. There are no moments here of trauma or high drama, and no obvious examples that speak to questions of social justice. And yet, it is in moments such as these that possibilities available within educational settings are made or unmade. It is for these reasons that we support Lenz Taguchi's (2009) call for an 'ethics of imminence', an ongoing sensitivity by educators to what is made and unmade and to the ways in which people, things, as well as habits of being, knowing and noticing play through these educational (un)makings. Focusing on the moment-to-moment unfolding of events in this way affords rich insights into how meanings get made and how literacy is framed by researchers and early years staff.

In many ways the discussion so far reflects points that we have explored previously in our own work (Burnett and Merchant, 2018; forthcoming) and that have been well-made in other writing from posthuman and new materialist perspectives (e.g. Hackett and Somerville, 2017; Thiel and Jones, 2017). The point that we want to make in this article is that a focus on the momentary and ephemeral neglects other relations that are significant to what is going on. During our time in this setting we were also aware of other discourses, materialising for example in the learning objectives extracted from the EY curriculum displayed on laminated card in some areas of the classroom, or in staff discussions about record keeping and school development plans, and this underlines how activity is always connected to what happens in other times and places. Despite the complexity of the unfolding events as bodies and things 
assemble in the moment, there is always more - much of which may be peripheral or unobservable - more that exists in relation to these events, as the following alternate tracings illustrate. It is these alternate relationalities that we explore in the remainder of this article, as we argue that engaging with the social injustices associated with language and literacy in early childhood education requires us to move beyond a perspective that starts and stays with children in classrooms.

\section{Alternate tracings}

In this section we gesture towards other relationalities by presenting alternate sociomaterial tracings, tracings that suggest elements or events of different orders and timescales that intersect, both with the vignette discussed above, and with the wider data-set from which it is drawn. In preparing the way for this, we draw on the notion of multiplicity in which a variety of 'modes of ordering, logics, frames, styles, repertoires' are said to co-exist (Mol and Law, 2002: 7). An acknowledgement of multiplicity eschews attempts to reduce or simplify (educational) reality and emphasises heterogeneity, as seen in the complex coexistence of different bodies, discourses and materials. It is this sense that Kwa (2002:26) enjoins us to look down into 'the mundane crawling and swarming of matter'. This is not to advocate pluralism (the existence of multiple realities) but rather an uncompromising acknowledgement of coexistent complexity. The idea is often characterised by Mol's suggestion that the body is 'more than one but less than many' (Mol, 2002: 82), which she derives from Deleuze's conception of multiplicity. For Deleuze, multiplicity 'designates a set of lines or dimensions that are irreducible to one another' (Deleuze 1986: vii) but exist in relation to one another. Here we work from this image, following the ways in which post Actor Network Theory scholars have gone on to elaborate 'ontological multiplicity' (Mol, 2002:164) as a way of showing how there are multiple versions of what is real 'not just over time, but alongside one another at the same time' (Law and Singleton, 2014: 384)

We foreground this kind of multiplicity because it problematises the apparent immediacy or 'givenness' of our classroom vignette. The point we make here is that detailed accounts of classroom activity - even those that attempt to know classrooms differently and to trouble habitual ways of approaching literacy activity - cannot adequately account for social injustice unless they acknowledge the sociomaterial relations that operate and materialise across different scales in time and space, and the work that is variously done to hold these different ways of knowing together or apart. In other words looking down at complexity as it presents itself in the moment is not quite enough. Acknowledging multiplicity requires a wider reach it involves a focus on bodies that extends beyond an immediate interest in human physicality in the classroom.

In what follows, we present five alternate tracings intended to suggest multiplicity, that draw attention to the heterogeneous meshwork of relations that play into literacy education in different ways, interleaving two further tracings from this data-set with three others that engage with bodies from outside the classroom. This approach is impelled by Mol and Law's suggestion that: 'To make sense of multiplicity, we need to think and write in topological ways, discovering methods for laying out spaces, and for defining paths to walk through these' (Mol and Law, 2002: 8). Importantly, in referring to 'tracings' we do not suggest that these relational effects are always observable. Nor are our examples all the result of empirical work (e.g. in line with Latour's call to 'follow the actors' in tracing relations across time and space). Instead they are hypothesised, suggestive, imaginary even - intended to exemplify how some of the material-social effects that play out in different sites and across sites are implicated in what children do in early years settings and how what they do is valued or 
devalued. The tracings are intended to suggest 'what if', to consider what happens to our ways of knowing young children's literacy in educational settings if we hold these multiple tracings together, and what this might mean for thinking about social injustice.

\section{Alternate Tracing 1 -turning to the iPads}

What happens, then, if we shift our intention to the touchscreen tablets? First of all, as suggested above, the way in which these tablets were introduced into the setting already implied particular kinds of uses. Even before the start of the project, the information sheet that we provided to staff as part of our ethical approval process explicitly stated what we were interested in, framing the devices as things that were used by young children and that could provide learning opportunities.

We want to know more about how young children use tablets at preschool and the views of parents, carers, and teachers on children's use of tablets at home and preschool. These findings will provide important insights about how we can best use tablets to support early learning.

From: 'An exploration of pre-school children's interactions with touchscreen tablets Staff information sheet'

This statement already carried with it ideas and assumptions about the educational benefits of technology (Selwyn, 2016), mapping onto professional discourses about the use of tablets in classroom learning. This was lent additional legitimacy through the interest and presence of university-based educational researchers. Although we observed children using touchscreen tablets in a variety of ways (as objects to walk or sit on, as surfaces on which to balance bricks, and so on), more often than not it was their screens that attracted attention and this was encouraged by adult gaze and interest (from the researchers, as well as well as from staff in the setting). In this way practices predicated on certain ideas about technology in education became salient, and occasions that had the 'appearance' of literacy attracted adult attention in ways that we have written about elsewhere (Burnett, Merchant and Neumann, 2019). Not only did this affect how adults conducted themselves, but we strongly suspect that it was also communicated implicitly to the children who seemed all too ready to perform literacy-like behaviours with the iPads.

By framing touchscreen tablets in this way, other ways of thinking about them fall into the background. For instance we easily forget that the use of touchscreen tablets is inextricable from the production and distribution of devices and apps that encourage and capitalise on new forms of social interaction and new discursive practices. As a result, as Paakari, Rautio and Valsmo (2019) demonstrate, introducing mobiles into classrooms involves school children in the circuit of invisible digital labour that underpins emerging economies submitting individuals to infringements of privacy, recasting them as producers of information for data mining and targeted advertising. Relationships between classroom iPad use and wider economic and environmental effects have received relatively little attention. Somehow young children's interactions with digital devices are held apart from all of this.

Tracing the iPads in an alternate direction takes us into the world of device and app design, the invisible workings of the technology, from the codes they rely on to the connections and circuitry that they depend upon - and eventually to the mineral extraction and labour conditions involved in their production. A fascination in young children's interest in these new technologies may blind us to the environmental impact of Bauxite extraction used to produce their sleek metallic finish and the cheap labour and damaging working conditions of 
those employed at places like Foxconn in Longua, China (Streeck, 2019). In earlier work we argued that:

If we recognise the anthropocene as an epoch distinct from prior geological eras, one in which human activity has shaped Earth's eco-systems and evolutionary processes in fundamental ways (Young, 2016), then the use of particular devices is not just about impact on specific communities of humans or other animals, or of tracing the significance of the production and use of digital devices to specific sites (although that is important, too), but it's about recognizing the ways in which consumption and use are interwoven with the future of the planet (Hodder, 2014). (Burnett and Merchant, 2017: 8)

In other words by looking in a different direction other forms of inequity and exploitation come into view - human as well as more-than-human. Our research brief, by focusing on children's use of technology, suggested an interest in what happens on a local scale. As such it held our interest in young children's use of technologies apart from broader concerns about childhood such as child labour in supply chains (see Gallagher, 2019).

\section{Alternate Tracing 2 -turning back to the local}

Despite what can be generated by looking beyond what is immediately apparent, in the spirit of multiplicity we argue that the local matters too. For instance, we could trace ways in which comparative data on social and economic deprivation play through analyses of educational attainment. We could draw attention to the fact that the research described in the vignette above took place in an early years centre located in the Yorkshire and Humber region of the UK. Formerly designated as an Early Excellence Centre, the unit serves a mixed semi-urban and rural area that has experienced the decline of the coal and steel industries. Of course this industrial decline was itself shaped by political responses to wider economic trends and perhaps unsurprisingly Early Excellence Centres were, more often than not, located in areas of economic deprivation (Ofsted, 2004). As we know, the geographical area in which a child lives is commonly cited as a predictive factor of educational attainment (Social Market Foundation 2016), and this is a salient issue in educational planning in this region. For example, in reflecting on recent trends Dunachik et al. (2018) describe how:

In 2007 the highest performing regions were spread widely across England. The East of England, the South East and the South West, closely followed by the North West and the East Midlands performed highest, whereas London, Yorkshire and the Humber and the North East were the lowest performing regions. (Dunachik, Wishart, Cartegena-Farias and Smith, 2018: 22).

Read against such statements, the setting's aim to improve the life chances of young children and their families might be seen to suggest that there is some catching up to do, particularly since Dunachik et al. report that children in Yorkshire and Humber have the lowest scores across the regions - the lowest scores based on the BAS II scale of vocabulary. Such analyses are the basis for multiple interventions and projects, many designed to support language and literacy development. For example in May 2019, The South Yorkshire Futures project, announced a ' $£ 1$ million project to improve speech and language development for the underfives' (South Yorkshire Futures, 2019). So it seems that the local matters. It matters in the sense that where children grow up may be used to predict their linguistic needs even before they have demonstrated them. And educational provision may already be targeted on fixing a 'problem' that has yet to manifest, and arguably, in so doing, helps to produce the problem. 
In this sense we might again evoke Law and Singleton (2014: 381) who suggest that 'policy is enacted into being'.

\section{Alternate Tracing 3 - turning to the staff}

And yet the local manifests in other ways too, as illustrated by the following story- written following a meeting with staff to review the video data from the project:

'There's Callum', says someone. 'Oh- I thought it was Lucas', says another. Can you replay the video?' GUY does so and they lean in, across the table, squinting to try and make out which children are appearing in the frame. One of the children turns around, showing his face - 'Ah - it is Lucas', 'Yes, it is', and a warm sigh of recognition 'Aaaaaaah... yes'. They lean back. All are smiling. It's not really surprising that they don't recognise this child at first. This video was taken eighteen months ago and some of these children have moved on, to school. The child on screen looks just like his younger brother does now. But, as we cluster round a table on a sunny May afternoon, there is something about the warm sigh of recognition that speaks of these early years' teachers' deep - and shared - sense of knowing that child, of a knowing and caring that exceeds any evaluation they may make of his language. Knowing, and recognising, that child matters. And that is an intensely local knowledge.

This story might be read (or told) in many ways- but here we include it to signal how care, deep familiality - and even love - may inflect adults' relations with the children in early childhood settings. In other tracings, we reflect on our own actions to explore how adults can work to promote and reign in certain ways of being a child. Here we foreground human relationality and intimacy to highlight the ways in which practitioners' engagement with young children exceeds what is attributable to socialisation and control. Of course such intimacy can assemble with other purposes and practices in many ways, and assumed knowledge of children can itself generate self-fulfilling expectations for what children do or who they can be. But here we suggest that such feelings of intimacy - through their warmth and generosity - may open out potentiality. Through thinking - and feeling - with multiplicity, we do not simply want to signal how injustice is upheld through different modes of knowing, but to point to how relations may assemble in ways that evoke other ways of being.

\section{Alternate Tracing 4 -turning to the Early Years Toolkit}

Clicking through the Education Endowment Foundation (EEF)'s site (https://educationendowmentfoundation.org.uk/), it would be hard for anyone unfamiliar with the organisation to work out their constitution or origins. In the style of many contemporary websites, designed to be easily accessed from a smartphone, there is plenty of open space and easy navigability but not much text, and context therefore is rather hard to locate.

Nevertheless, it is easy to infer what the EEF cares about: evidence, the attainment gap and practical, cost-effective interventions. A click on a turquoise button generates an introductory blurb for an Early Years Toolkit: a set of links to summaries of neatly parceled interventionstagged as communication and language approaches, digital technology, play-based learning, early literacy and so on - evaluated over fixed time periods using randomised controlled trials. Next to each is a telling set of icons (pound signs, padlocks, numerals - they all do their work) indicating ratings for cost, reliability of evidence, and impact on learning in months - in short, their market value. 
Attempts to bring evidence to practice in this way bring with them methodological and ideological challenges (e.g. see Biesta, 2010; Dawson, Yeomans and Brown, 2018; Rømer, 2019), and consequently the realities may belie the site's authoritative presentation of the relative benefits of different interventions. Here, however, we are interested in how the site itself works to help to sustain educational realities, operating as it does through multiple sets of heterogeneous relations: the freely and easily navigable architecture, for example that distils complex educational practices into transferable, actionable truths; its origins in EEF's offer of funding for research and practice at a time when funding sources are few and far between; and the cause-effect logic of randomised controlled trials that requires the packaging of educational activity into identifiable bite-sized chunks. These different phenomena, produced through multiple sociomaterial relations, arguably stabilise one another as they come into relation with the discourses of school autonomy, high-stakes accountability and marketisation that have dominated the English educational system over the last three decades.

\section{Alternate Tracing 5 - turning to the researcher}

$W$ is told to get a tissue and wipe his nose. He finds a tissue but then comes up to me, hands me the tissue and stands there expectantly. I take the hint and wipe away. He wanders off and I'm left with a tissue. Fortunately I see a bin. I guess this positions me in the servant role. Later someone else comes to me and presents me with their empty cup, so I take it and thank him. Clearly this is a mistake as L. gently prompts, 'Are you asking for more drink?', and I get the message and pour him some more drink- at least I have a role. But then of course someone else - W I think-asks me to give him some more, going up to the milk jug with his cup. Now confident of my role, I start to pour - 'O so it's self-service now' offers an adult gently. The comment is to $W$, but I feel it's really meant for me, and I sense I shouldn't have been quite so willing to oblige. Windicates that he'd also like some snack and I pass him the plate- 'Shall we see if anyone else wants a snack' offers an adult, and I realise I've got it wrong again. As adult I should have been the one to prompt $W$ to share. An awkward giant that just doesn't know the rules.

In many ways perhaps Cathy's ineptitude and insensitivity to the unspoken rules of the setting mirrors the children's. Like them s/he is learning to move in certain ways, eek out resources as expected, and to understand the politics of power and turn-taking. Of course socialising children into the management of bodies and things is a key part of what goes on in educational settings, and children are expected to learn to manage their bodies and stuff in ways that work within educational institutions. But while such practices have frequently been the subject of critique (e.g. Dixon, 2011), Cathy's feeling of being the wrong body in the wrong place is visceral. Whatever her intellectual analysis of what's happening, she feels an urge to align her management of bodies and things with those of the other adults, to read and respond to children's bodily actions more as they do, and in doing so to feel a bit more like she fits in.

This suggests an underlying motif in educational provision, namely that adults and children must not only conform to particular ways of doing things but that these should feel right, too. Bodies and things need to align in quite specific ways in order to count as legitimate performances. Acting and speaking in 'appropriate ways' can then be approached as materialsemiotic practices that have become naturalised, and of course this extends to the ways in which early literacy is construed and parsed by children and adults. 


\section{Staying with multiplicity}

These five tracings are indicative of the complex interweavings of bodies, things and discourses that help to produce the multiplicity of everyday life in a single educational setting. They are, of course, not a complete set and could never be so. Other tracings might, for example: have been told from the perspectives of children, adults or parents; hinted at the participation of more-than-human lives in events described, or tracked the movements of media to and from the early childhood setting. However, they work alongside the opening vignette in order to thicken the plot. Importantly, they evoke bodies in different ways. The tracings variously tell of disciplining bodies, reading bodies, counting bodies and managing bodies, and sometimes they erase bodies altogether. They also tell of bodies that leak, that strike out, that feel like they belong, or feel out of time or place. Implicit within the tracings are different theorisations of moving bodies (Enriquez et al., 2016): which variously link bodies and discourses, which foreground emergence and affect, or which erase the body altogether. But to stay faithful to the idea of multiplicity it is necessary to avoid the temptation to tidy up this messy coexistence of disparate elements, these different orders of knowing, in favour of a single overarching argument. As Law argues, 'simple clear descriptions don't work if what they are describing is not itself coherent.' (Law, 2004: 2). After all, how can we hold together worker suicides at Foxconn (Streeck, 2019) with the warm sighs of the teachers watching videos of children with touchscreen tablets? How can we hold together the properties of sand as it runs through the fingers with pervasive narratives of language deficit? And how can we hold the awkwardness of the researcher's body with the imperative to perform academic coherence? Of course we can try, but there will always be tensions if we work with multiplicity. It might be better to accept that 'the social processes that we study and our own take on them are incomplete, uncomfortable, on the move and without resting places where everything can fit together (Law and Singleton, 2014: 381). It might be more productive then to 'stay with the trouble' (Haraway, 2016: 1)) by 'learning to be truly present [...] as mortal critters entwined in myriad unfinished configurations of places, times, matters and meanings.' In order to disturb any suggestion of convergence - or indeed completion- in the above tracings, we deliberately destabilise things with some notes for other tracings that imagine other ways of reading bodies and things. Notes on other tracings - Halloween, 2017

1. Coal, yes coal. It would be good if you could include a lump of coal. Decayed plant matter buried in deep time. Dug up - carbon fuel propelling industrial expansion. Spoil heaps, now greened over, fracking a constant threat. Coal not dole. And then it was all over. Dole becomes universal credit, thin protection against post-industrial ennui.

2. A height chart. Feet and inches or metres? Does that matter as much to us as it does to Donald Trump? Year by year your child grows. Is she taller than her friend. How's she doing? Measurement, comparison. She seems so small.

3. Witches. Alice Molland hanged in Exeter 1682 (the last execution, but persecution reaches into the $19^{\text {th }}$ Century). An oppression of women. Trick or treat? Ducking stools. Halloween. Burnt at the stake.

4. A map, after all we are in a region. Separated off from the rest of the country, perhaps. Which country? England. A representation of voting patterns might fit in here. Are we voting to enlarge the English Channel, perhaps? The United Kingdom a sovereign state. How does Brexit play out in this particular part of the country?

5. Sand. Where does it come from? Where does it go? Sand in the classroom, sand on the floor, sand in special sandtrays, sand travelling home under the fingernails. Is sand as old as coal? 


\section{Dressing up. \$7.00 for a Halloween costume for your child. Buy it online, Amazon Prime, next day delivery. Fancy dress, made in China.}

It would be against the spirit of the disruption intended to offer a detailed commentary or analysis on these notes. Suffice it to say that they gesture towards narratives of growth and measurement, things that can be bought and sold in an economy of affluence, to geographical distribution and historical connection as well as to the texts produced by researchers. It is central to our argument that these are all folded into the work we describe, and that our challenge - as researchers and educationalists- is to work with the mess of these multiple, and inter-imbricated ways of knowing children, language and literacy in classrooms. Doing this is necessary if we are to avoid simply replacing old coherent narratives with new ones. As we explored earlier, the recent insertion of posthumanism in literacy studies (see for example: Collier and Harwood, 2017; Wargo, 2017 and Hackett and Somerville, 2017) has made two important contributions: first, it has explained how deficit discourses are themselves sustained through sociomaterial relations, and second, it has exposed the inadequacy of deficit perspectives by presenting alternate accounts. Our contribution here is to suggest that holding together these two perspectives - and more - is important if we are to engage in questions of social justice in ways that acknowledge the complexity and multiplicity of what goes on in educational settings, if we are to continue to probe questions of ethics, and if we are to intervene in ways that work to disrupt the practices we set out to critique. The alternate tracings we have imagined may or may not relate directly to the work and play of children and classrooms, but many of them are likely to have implications for the kind of provision children encounter, for how they are perceived (by themselves, by parents, by teachers, by the media and so on), for how these things take shape in the moment and indeed for how those particular shapes are valued. Importantly, then, a focus on the moment is not just about ephemerality.

The deficit discourse cannot be ignored by a sociomaterialist account, and although our alternate tracings underline the way in which other stories can always be told, they may seem minor in comparison. This is partly because of the tendency of dominant discourses to reemerge, mutate and reassemble, as in the way in which moral panics about screen time have attached to ideas about the word gap. A recent example of this mutation is the way in which Ofsted, the government organisation for monitoring educational quality in England, has appropriated Bourdieu's notion of cultural capital (Bourdieu, 1991), recasting it in terms of the 'essential knowledge that children need to be educated citizens':

142. Cultural capital is the essential knowledge that children need to prepare them for their future success. It is about giving children the best possible start to their early education. As part of making a judgement about the quality of education, inspectors will consider how well leaders use the curriculum to enhance the experience and opportunities available to children, particularly the most disadvantaged.

143. Some children arrive at an early years settings with different experiences from others, in their learning and play. What a setting does, through its EYFS curriculum and interactions with practitioners, potentially makes all the difference for children. It is the role of the setting to help children experience the awe and wonder of the world in which they live, through the seven areas of learning.

(Early Years Inspection Handbook, 2019: 32)

As cultural capital has assembled with accountability measures, and established traditions of individualised learning, it is refigured as a desirable quality which by implication some 
children have and others do not, rather than the knowledge and experience that all children and all families have (as Bourdieu demonstrated).

Alternate tracings, however, offer a possibility of potential variation, or a new mode of valuation. In arguing for this we draw on Manning's (2016) work on the minor gesture which attempts to 'cut across narrative accounts of what it is to know' (p. 27), to disturb dominant or 'major' tropes. Manning suggests that:

The major is a structural tendency that organizes itself according to predetermined definitions of value. The minor is a force that comes through it, unmooring its structural integrity, problematizing its normative standards. [....] In its movement, the minor gesture creates sites of dissonance, staging disturbances that open experience to new modes of expression. In making felt the event's limit, the operational interval where the event exceeds the sum of its parts, the minor gesture punctually reorientates experience. (Manning, 2016: 1-2).

It is this disturbance or interruption that we aim to provoke by juxtaposing multiple tracings. In many ways these tracings reflect the inconsistencies and contradictions that, as we argued earlier, inflect many teachers' discussions of professional practice as they work to accommodate personal commitments with professional and societal discourses. Our own experience of professional discussions around literacy and technology, for example, is that they lurch between a fascination for what children can do with technologies, to excitement about the potential of technology in education, to concern for what children are missing and the effects variously on their sociability, health and language. Just as classrooms are complex places inflected by multiple ways of knowing and doing, so too are professional conversations.

By bringing alternate stories into conversation with one another, however, we aim to open out spaces whereby other kinds of conversation can be held. How, for example, is the resourcing of early years education complicit in networks of practices that sustain injustices elsewhere (for humans and other species), and that will help to shape the places in which these children live and will grow up? And even with the best intentions, how can we escape ways of being and doing inscribed on bodies over time? Doing this, we propose, involves holding together a focus on the material social relationality of classrooms with those material social relations that enact and inform professional thinking and practice. Accounts of practice - whether these be in the form of statistical summaries of attainment based on standardised assessments or fine-grained stories of human/non-human engagements - are always representations of moments from which vitality has escaped. However the sharing of such accounts is itself is generative of potentialities, as dominant ideas assemble with multiple ways of being and doing through embodied encounters.

It is beyond the scope of this paper to describe how an evocation of multiplicities can interfere with or interrupt dominant discourses (although this is an important area for research and an emphasis of our ongoing work). Our focus here has been to complicate the possibilities of posthumanism in literacy education by imagining multiple sociomaterial tracings through moments unfolding in one setting. To do this we have juxtaposed commentary on a short vignette from classroom practice with five alternate and tentative tracings of other kinds of relations that play through those moments, linked for example to the sociomaterial relations that inflect the circulation of ideas, dominant forms of evidencebased practice, and indeed our own research processes. We have considered how such 
relations can work to uphold particular kinds of practice and particular arrangements of bodies and things over others, thereby favouring groups of children who perform and reproduce accepted and acceptable ways of being and doing, but we have also suggested that as these different relations interface and interfere with one another, alternate possibilities for thinking, doing and being may open out. Through a series of tracings and retracings of relations that each trouble one another in their inadequacy, we sketch a possible agenda for research that works with multiplicity to both better account for relationships between social inequality and materiality in educational settings, but that also includes an activist dimension, through which researchers work disruptively to challenge and unsettle the kinds of practices that sustain inequality.

\section{References}

Adair JK, Colegrove KS and McManus ME (2017) How the word gap argument negatively impacts young children of Latinx immigrants' conceptualizations of learning. Harvard Educational Review 87(3): 309-334.

Alsup J (2006) Teacher identity discourses: Negotiating personal and professional spaces. Malwah, New Jersey: Lawrence Erlbaum Associates.

Baugh J (2017) Meaning-less differences: exposing fallacies and flaws in "the word gap" hypothesis that conceal a dangerous "language trap" for low-income American families and their children. International Multilingual Research Journal 11(1):39-51.

Biesta G (2010) Why what works still won't work: from evidence-based practice to valuebased education. Studies of Philosophy in Education 29:491-503.

Bourdieu P (1991) Language and symbolic power. Oxford: Blackwell.

Burnett, C., Daniels, K, Gray, L., Myers, J. \& Sharpe, S. (2015). Investigating studentteachers' presentations of literacy and literacy pedagogy in a complex context. Teacher Development 19(3): 275-293.

Burnett, C. \& Merchant, G. (forthcoming). Undoing the Digital: Sociomaterialism and Literacy Education. London: Routledge.

Burnett, C. \& Merchant, G. (2018). Literacy-as-event: accounting for relationality in literacy research. Discourse: Studies in the Cultural Politics of Education.Online First.

Burnett, C. \& Merchant, G. (2017). The case of the iPad. In C. Burnett, G.Merchant, A.Simpson, M. Walsh (Eds.), Mobile Literacies: The Case of the iPad in Education. New York: Springer (pp.1-

14).Burnett, C., Merchant, G., Neumann, M. (2019). The appearance of literacy in new communicative practices: interrogating the politics of noticing. Cambridge Journal of Education. Online First.

Comber B (2014) Literacy, poverty and schooling: What matters in young people's education? Literacy 48(3): 115-123.

Comber B and Kamler B (2005) Turn-around pedagogies: Literacy interventions for at-risk students. Primary English Teaching Association.

Cummins J (2009) Transformative multiliteracies pedagogy: School-based strategies for closing the achievement gap. Multiple Voices for Ethnically Diverse Exceptional Learners 11(2): 38-56.

Creber J (1972) Lost for words: Language and educational failure. London: Penguin. Daniels K (2018) Movement meaning and affect: The stuff childhood literacies are made of. Doctoral thesis. Sheffield Hallam University. Available at http://shura.shu.ac.uk/21513/. Accessed $31^{\text {st }}$ May 2019.

Dawson A, Yeomans, E and Brown ER (2018) Methodological challenges in education RCTS: Reflections from England's Education Endowment Foundation. Educational Research 60(3): 292-310. 
Deleuze G (1986) Preface to the English Language Edition. In Deleuze G and Parnett C Dialogues II. London: Continuum, pp. i-x.

Dixon K (2011) Literacy, power and the schooled body: Learning in time and space. New York: Routledge.

Dunatchik A, Wishart R, Cartegena-Farias J and Smith N (2018) Regional differences in attainment in the early years. Department for Education (DfE). Available at

https://www.gov.uk/government/publications/regional-differences-in-attainment-in-the-earlyyears. Accessed $31^{\text {st }}$ May 2019.

Education Endowment Foundation (EEF) (2018) Teaching and Learning Toolkit. Available at: https://educationendowmentfoundation.org.uk/evidence-summaries/teaching-learningtoolkit/. Accessed 31 ${ }^{\text {st }}$ May 2019.

Enriquez G, Johnson E, Kontovourki S and Mallozi C.(eds) (2016) Literacies, learning and the body: Putting theory and research into pedagogical practice. Abingdon, Oxon:

Routledge.

Fernald A, Marchman VA and Weisleder A (2013) SES differences in language processing skill and vocabulary are evident at 18 months. Developmental Science 16 (2): 234-48.

Gallagher M (2019) Childhood and the geology of media. Discourse: Studies in the Cultural Politics of Education. Available at

https://www.tandfonline.com/doi/full/10.1080/01596306.2019.1620481

Guest I (2018) Exploring teachers' professional development with Twitter: a sociomaterial analysis. Doctoral thesis. Sheffield Hallam University. Available at

http://shura.shu.ac.uk/24081/1/Guest_2018_PhD_ExploringTeachers\%27Professional.pdf.

Accessed $24^{\text {th }}$ September 2019.

Hackett A and Somerville M (2017). Posthuman literacies: Young children moving in time, place and more-than-human worlds. Journal of Early Childhood Literacy, 17(3): 374-391.

Haraway D (2016) Staying with the trouble: Making kin in the Chthulucene. London: Duke University Press.

Harley J (2018) Why closing the language gap matters: Oxford Language Report. Available at http://fdslive.oup.com/www.oup.com/oxed/Oxford-Language-Report.PDF?region=uk.

Accessed $31^{\text {st }}$ May 2019.

Hart B and Risley TR (1995) Meaningful differences in the everyday experience of young American children. Baltimore: Brookes.

Hattie J (2008) Visible learning. London and New York: Routledge.

Heath SB (1983) Ways with words: Language, life and work in communities and classrooms.

Cambridge: Cambridge University Press.

Hodder I (2014) The entanglements of humans and things: A long-term view. New Literacy

History 45 (1): 19-36

Institution of Education Sciences (IES) (2018) What Works Clearinghouse. Available at:

https://ies.ed.gov/ncee/wwc/. Accessed $31^{\text {st }}$ May 2019.

Kelly N and Antonio A (2016) Teacher peer support in social network sites. Teaching and

Teacher Education 56: 138-149.

Kuby C, Spector K and Thiel J (eds) (2019) Posthumanism and literacy education:

Knowing/becoming/doing literacies. New York: Routledge.

Kwa C (2002) Romantic and baroque conceptions of complex wholes in the sciences. In Law J and Mol A (eds) Complexities: social studies of knowledge practices. London: Duke University Press, pp.23-52.

Law J (2004) After method - Mess in social science. London: Routledge.

Law J (2008) Actor network theory and material semiotics. In Turner B (ed) The new

Blackwell companion to social theory. Oxford: Blackwell, pp.141-158. 
Law J and Mol A (eds) (2002) Complexities - Social studies of knowledge practices. London: Duke University Press.

Law J and Hassard J (eds) (1999) Actor network theory and after. Oxford: Blackwell. Law J and Singleton V (2014) ANT, multiplicity and policy. Critical Policy Studies 8(4): 379-396.

Lenz Taguchi H (2010) Going beyond the theory/practice divide in early childhood education. London: Routledge.

Manning E (2016) The minor gesture. London: Duke University Press.

Manning E (2014) Wondering the world directly - or how movement outruns the subject. Body and Society 20(3-4): 162-188.

Massumi B (2002) Parables for the virtual: Movement, affect, sensation. London: Duke University Press.

McCarty TL (2015) How the logic of gap discourse perpetuates education inequality: A view from the ethnography of language policy. Journal of Linguistic Anthropology 25(1): 70-71. Mol A (2002) The body multiple: Ontology in medical practice. London: Duke University Press.

Mol A and Law J (2002) Complexities: an introduction. In: Law J. and Mol A (eds). Complexities - Social studies of knowledge practices. London: Duke University Press, pp 122.

Ofsted (2004) Children at the centre: an evaluation of early excellence centres. Available at:https://dera.ioe.ac.uk/7343/1/Children\%20at\%20the\%20centre\%20an\%20evaluation\%20of $\% 20$ early\%20excellence\%20centres\%20\%28PDF\%20format\%29.pdf

Ofsted (2019) Early years inspection handbook for registered provision. May 2019. Available at: https://www.gov.uk/government/publications/early-years-inspection-handbook-eif. Accessed $19^{\text {th }}$ May 2019.

Paakari A, Rautio P and Valsmo V (2019) Digital labour in school: Smartphones and their consequences in the classroom. Learning, Culture and Social Interaction 21: 161-169. Quigley A (2018) Closing the vocabulary gap. London: Routledge.

Rømer TA (2019) A critique of John Hattie's theory of Visible Learning. Educational Philosophy and Theory 51(6): 587-598.

Social Market Foundation (2016) Educational inequalities in England and Wales:

Commission on Inequality in Education. Available at:

http://www.smf.co.uk/wpcontent/uploads/2016/01/Publication-Commission-on-Inequality-inEducation-InitialFindings-Slide-Pack-120116.pdf. Accessed 20 ${ }^{\text {th }}$ May 2019.

South Yorkshire Futures (2019) Available at:

https://southyorkshirefutures.co.uk/syf/2019/05/10/south-yorkshire-futures-leads-1-millionproject-to-improve-speech-and-language-development-for-under-fives/. Accessed $20^{\text {th }}$ May 2019.

Souto-Manning M and Yoon H (2018) Rethinking early literacies: Reading and rewriting worlds. New York: Routledge.

Streeck W (2019) Through unending halls. London Review of Books 4(3): 29-31.

Thiel J and Jones S (2017). The literacies of things: Reconfiguring the material-discursive production of race and class in an informal learning centre. Journal of Early Childhood Literacy, 17(3):315-335.

Wells G (1999) Dialogic inquiry: Towards a socio-cultural practice and theory of education. Cambridge: Cambridge University Press.

Young K (2016) Biogeography of the anthropocene. Progress in Physical Geography 40(1): 161-174. 